\title{
Microbial Community Structure, Pigment Composition, and Nitrogen Source of Red Snow in Antarctica
}

\author{
Masanori Fujii • Yoshinori Takano • Hisaya Kojima • \\ Tamotsu Hoshino • Ryouichi Tanaka • Manabu Fukui
}

Received: 3 September 2009 / Accepted: 19 September 2009 /Published online: 22 October 2009

(C) Springer Science + Business Media, LLC 2009

\begin{abstract}
Red snow" refers to red-colored snow, caused by bloom of cold-adapted phototrophs, so-called snow algae. The red snow found in Langhovde, Antarctica, was investigated from several viewpoints. Various sizes of rounded red cells were observed in the red snow samples under microscopy. Pigment analysis demonstrated accumulation of astaxanthin in the red snow. Community structure of microorganisms was analyzed by culture-independent methods. In the analyses of small subunit rRNA genes, several species of green algae, fungus, and various phylotypes of bacteria were detected. The detected bacteria were closely related to psychrophilic or psychrotolerant heterotrophic strains, or sequences detected from lowtemperature environments. As predominant lineage of bacteria, members of the genus Hymenobacter were consistently detected from samples obtained in two different years. Nitrogen isotopic compositions analysis indicated that the red snow was significantly ${ }^{15} \mathrm{~N}$-enriched. Based on
\end{abstract}

M. Fujii $\cdot$ H. Kojima $(\bowtie) \cdot$ R. Tanaka $\cdot$ M. Fukui $(\bowtie)$

The Institute of Low Temperature Science, Hokkaido University,

Kita-19, Nishi-8, Kita-ku,

Sapporo 060-0819, Japan

e-mail:kojimah@pop.lowtem.hokudai.ac.jp

e-mail: my-fukui@pop.lowtem.hokudai.ac.jp

\section{Y. Takano}

Institute of Biogeosciences,

Japan Agency for Marine-Earth Science and Technology,

2-15 Natsushima,

Yokosuka 237-0061, Japan

\section{T. Hoshino}

Institute for Biological Resources and Function,

National Institute of Advanced Industrial Science and Technology,

2-17-2-1 Tsukisamu-Higashi, Toyohira-ku,

Sapporo 062-8517, Japan an estimation of trophic level, it was suggested that primary nitrogen sources of the red snow were supplied from fecal pellet of seabirds including a marine top predator of Antarctica.

\section{Introduction}

In high-altitude or high-latitude areas, red, orange, and green colors are occasionally observed on snowfields during the snow-melting period. Red-coloring of snow is commonly called "red snow", and known to be caused by a bloom of specific unicellular algae. These algae, referred to as snow algae, adapt to harsh environments such as low temperature, nutrient depletion, and excessive UV irradiation [16]. Cells of some snow algae species (e.g., Chlamydomonas nivalis) contain a high concentration of a red pigment, astaxanthin, which is thought to act as a shield against excessive UV irradiation.

Red snow has been observed in many parts of the world such as alpine and high latitude of Europe [28], western North America [45], Australia, New Zealand [25, 32, 49], South America [47], North Africa [11], Arctic regions [38], and coastal Antarctica and surrounding islands [29]. Although size of colored region varies from site to site, wide-area research based on remote sensing revealed presence of substantial biomass in the colored snowfield $[39,46]$. These findings may imply that the snow algae are highly productive in spite of harsh environmental conditions on the surface of snow. In fact, high rates of $\mathrm{CO}_{2}$ uptake have been observed in the blooms of snow algae [55]. It also has been reported that these snow algae play an important role as primary producers, which sustain a community consisting of cold-adapted organisms such as the ice worm, collembola, and bacteria $[15,44,50]$. 
Red snow has been recognized as an indigenous phenomenon that occurs in certain localities. In addition, remote sensing analyses revealed heterogeneous distribution of algal cells among and within snowfields [39, 46]. At the present time, however, little is known about the factors controlling the occurrence and distribution of red snow (e.g., [30, 38]). Although involvement of nutrient availability was suggested [16], cause of the heterogeneous distribution has not been fully explained. It is well known that specific bacterial activities have significant influence on nutrient availability. Previous studies reported the presence of numerous bacteria surrounding snow algal cells $[17,50,54]$, but their phylogenetic affiliations were not identified. Their physiological properties are also unrevealed, and therefore, it is unknown whether these bacteria are essential components of red snow or mere secondary inhabitants.

One of the most effective ways to deduce nutrient source is stable isotope analysis. Stable isotope analysis of bulk organic materials has been employed as a method for investigating food web structure in a number of ecological studies (for review, see [13]). Since the pioneering work in 1980s (e.g., [10, 34]), the nitrogen isotopic composition $\left(\delta^{15} \mathrm{~N}\right)$ of bulk organisms and their tissues has been widely used in elucidating the trophic levels of organisms and nitrogen flow in a food web.

Here, we characterized red snow found in Langhovde along the Lützow-Holm Bay, East Antarctica. Besides basic characterization, including pigment analysis and phyloge- netic identification of causal snow algae, community structure of associated bacteria was also analyzed to investigate roles of these bacteria in the blooming phenomenon. In addition, nitrogen isotopic compositions of the red snow samples were determined to deduce source of nutrient supply that might have been determinative factor of red snow distribution.

\section{Methods}

\section{Sample Collection}

Samples of red snow were obtained in January 2006 and February 2007 , from a site $\left(69^{\circ} 14.9^{\prime} \mathrm{S}, 39^{\circ} 44.8^{\prime} \mathrm{E}\right)$ in Yatude Valley, Langhovde, Antarctica (Fig. 1). A portion of the samples obtained in 2006 were thawed on site, and fixed with glutaraldehyde ( $1 \%$ final concentration) for enumeration of algal cells. From another fraction of the snow melt, particulate substances were collected on $0.22 \mu \mathrm{m}$ filters (Sterivex filter cartridges; Millipore, Billerica, MA) until clogging occurred $(150 \mathrm{ml}$ of the snow melt was filtered). The filters were frozen immediately, and kept at $-80^{\circ} \mathrm{C}$ until DNA extraction. The other part of the snow sample was kept at $-80^{\circ} \mathrm{C}$, until processing in the laboratory. The sample obtained in 2007 was also stored at $-80^{\circ} \mathrm{C}$. The stored samples were thawed at $5^{\circ} \mathrm{C}$ for the following analyses. As basic characteristics of the snow melt, concentrations major ions were determined by ion chromatography,

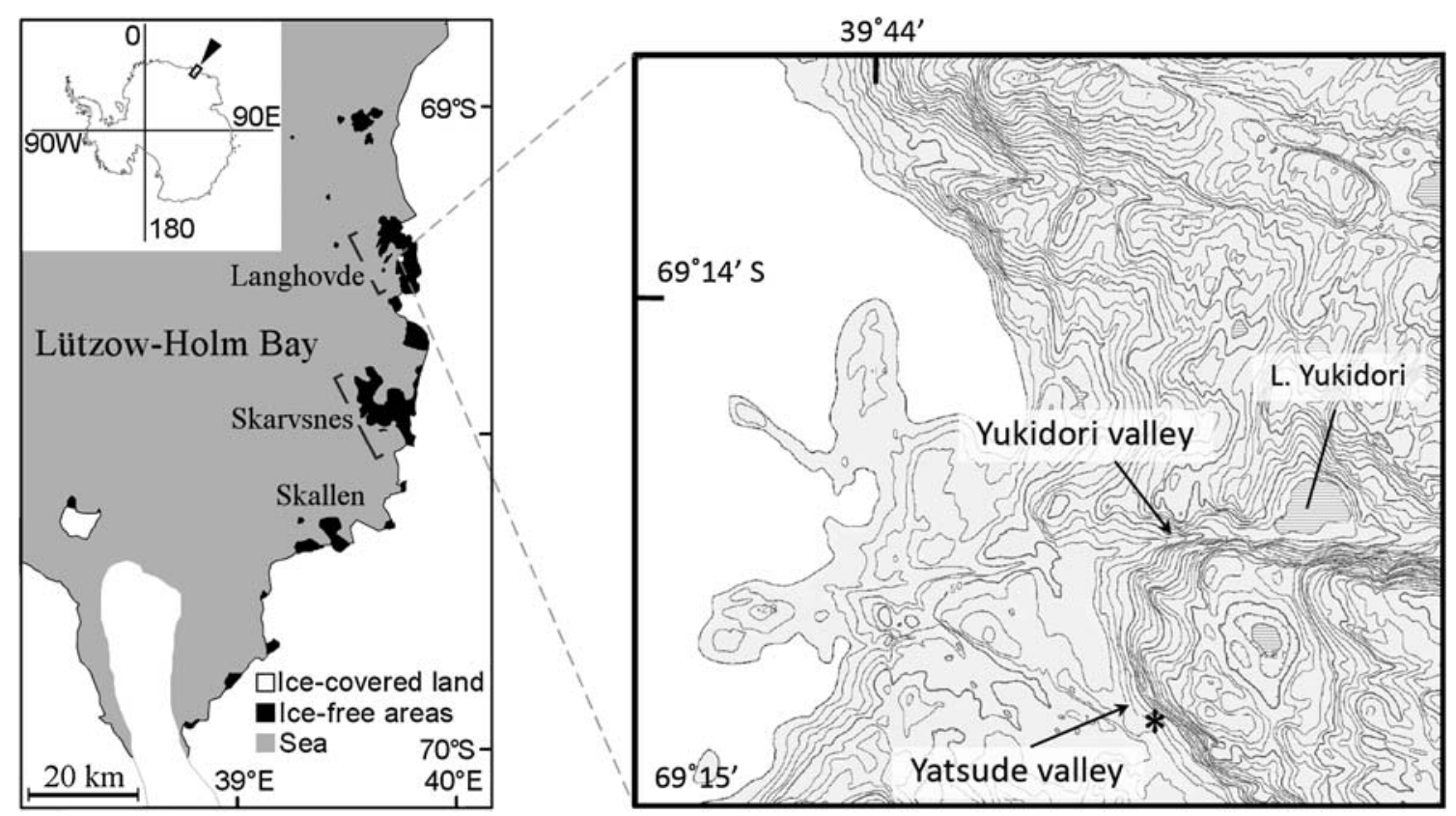

Figure 1 Map of the sampling site in Langhovde, Antarctica. The sampling site is indicated with an asterisk 
as follows; $\mathrm{NO}_{3}{ }^{-}, 0.09 \mu \mathrm{M} ; \mathrm{PO}_{4}{ }^{3-}, 0.85 \mu \mathrm{M} ; \mathrm{SO}_{4}{ }^{2-}$, $0.15 \mu \mathrm{M} ; \mathrm{Cl}^{-}, 6.56 \mu \mathrm{M} ; \mathrm{NH}_{4}^{+}, 5.2 \mu \mathrm{M} ; \mathrm{K}^{+}, 2.24 \mu \mathrm{M}$; $\mathrm{Mg}^{2+}, 0.86 \mu \mathrm{M} ; \mathrm{Ca}^{2+}, 1.5 \mu \mathrm{M}$ (Fukui, unpublished data). For the DNA based analyses, $50 \mathrm{ml}$ of the snow melt was filtered.

\section{Cell Enumeration}

From the fixed samples snow melt $(70 \mathrm{ml}$ of 2006 sample and $40 \mathrm{ml}$ of 2007 sample), cells were adequately condensed by centrifugation and then dispersed by sonication. Red cells in the samples were counted under a microscope by using a Thoma chamber. For each sample, values from ten measurements were averaged.

\section{Pigment Analysis}

Pigments were extracted from the snow samples obtained in 2006 , stored at $-80^{\circ} \mathrm{C}$. Immediately after acetone extraction, a small aliquot of extracts (typically 10-20 ml) was subjected to HPLC analysis using the Shimadzu LC-10AT HPLC system (Shimadzu Co. Ltd, Kyoto, Japan) equipped with a photodiode array detector (SPD-M20A; Shimadzu). Pigments were separated on a C18 reverse phase column, ShimPack VP-ODS $(250 \times 4.6 \mathrm{~mm}$; Shimadzu $)$, at an ambient temperature around $25^{\circ} \mathrm{C}$ according to the method of Sarada et al. [42]. The mobile phase consists of Solvent A (methanol: $\mathrm{H}_{2} \mathrm{O}=9: 1[v / v]$ ) and Solvent B (acetone). The flow rate was $1.25 \mathrm{ml} \mathrm{min}^{-1}$. At the time of injection, the mobile phase was $80 \% \mathrm{~A}$ and $20 \% \mathrm{~B}$, and the $\mathrm{A}$ concentration was decreased linearly to $20 \%$ over $25 \mathrm{~min}$, then the same concentration was kept for $10 \mathrm{~min}$ to elute all esterified carotenoids. The eluate was monitored with the photodiode array detector in the range from $350 \mathrm{~nm}$ to $700 \mathrm{~nm}$. A standard trans-astaxanthin pigment purchased from Wako Pure Chemicals (Tokyo, Japan) and an acetone extract from leaves of Arabidopsis thaliana that contain chlorophylls, pheophytin $a$, lutein and other photosynthetic pigments were run on the same HPLC system to compare the retention time of each pigment with that of the Antarctic samples. For mass spectroscopic analysis, eluates corresponding to possible trans- and cis-astaxanthin peaks were collected manually by monitoring their absorbance spectra. To the collected fractions, trifluoroacetic acid and $\mathrm{H}_{2} \mathrm{O}$ were added to a final concentration of $0.05 \%$ and $10 \%$, respectively, to improve ionization of pigments for the subsequent electrospray ionization mass spectrometry (ESI-MS) using the AccuTOF system (MS-50010BU; JEOL Ltd., Tokyo Japan). Settings for ESI-MS were as

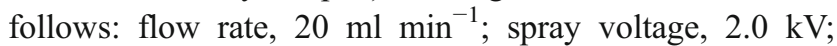
values were $m / z[\mathrm{M}+\mathrm{H}]+$. Reserpine, whose theoretical $\mathrm{m} / \mathrm{z}$ is 609.281 was co-injected with a sample as an internal standard for calibration.
Polymerase chain reaction-denaturing gradient gel electrophoresis (PCR-DGGE)

From the particulate samples of on the filters, DNA samples were prepared with the bead-beating methods described previously [24]. Fragments of bacterial $16 \mathrm{~S}$ rRNA genes were amplified with the primers GC341f and 907r [37]. For all PCR amplifications, TaKaRa Ex Taq kit (Takara Bio, Inc., Otsu, Japan) was used. The PCR solution consisted of $14 \mu \mathrm{l}$ of sterile water, $0.125 \mu$ of Ex Taq (5 units $\mu^{-1}$ ), $2 \mu$ l of 10x Ex Taq buffer, $1.6 \mu$ of dNTP mixture, $0.2 \mu \mathrm{l}$ of each primer solution $(25 \mu \mathrm{M})$, and $2 \mu \mathrm{l}$ of the template DNA solution. The amplification was initiated with $5 \mathrm{~min}$ of denaturation at $94^{\circ} \mathrm{C}$. Each thermal cycle consisted of $60 \mathrm{~s}$ of denaturation at $94^{\circ} \mathrm{C}, 60 \mathrm{~s}$ of annealing at $45^{\circ} \mathrm{C}$, and $60 \mathrm{~s}$ of elongation at $72^{\circ} \mathrm{C}$. The total cycle number was 30 , and an additional extension was carried out for $10 \mathrm{~min}$ at $72^{\circ} \mathrm{C}$. The amplified fragments were subjected to DGGE, using 1.5-mm-thick 6\% $(w / v)$ polyacrylamide gels (acrylamide:bisacrylamide $=37.5: 1$ ). The range of denaturing gradient was adjusted to $20 \%$ to $40 \%$ of urea and formamide (100\% corresponds to $40 \%$ $(v / v)$ formamide and $7 \mathrm{M}$ urea). The electrophoresis was run in $0.5 \times$ TAE buffer $(20 \mathrm{mM}$ Tris, $10 \mathrm{mM}$ acetic acid, and $0.5 \mathrm{mM}$ EDTA, $\mathrm{pH} 8$ ), at $60^{\circ} \mathrm{C}$ for $4 \mathrm{~h}$ at a constant voltage of $200 \mathrm{~V}$. The resulting bands were visualized by ethidium bromide stain and UV illumination. Several bands were cut from the DGGE gel, and DNA fragments in the pieces of gel were amplified with the same primer pair again. Small portions of the respective amplicons were subjected to DGGE again to confirm the formation of single bands at the proper positions. The confirmed amplicons were purified and then sequenced.

Community structure of eukaryotic organisms was also analyzed by PCR-DGGE, using the primers $960 \mathrm{FbGC}$ and 1200R [14]. The PCR amplification was initiated with 5 min of denaturation at $94^{\circ} \mathrm{C}$. Each thermal cycle consisted of $45 \mathrm{~s}$ at $94^{\circ} \mathrm{C}, 45 \mathrm{~s} 55^{\circ} \mathrm{C}$, and $45 \mathrm{~s}$ at $72^{\circ} \mathrm{C}$. The total cycle number was 30 , and additional extension was carried out for $10 \mathrm{~min}$ at $72^{\circ} \mathrm{C}$. Following DGGE analysis was performed as described above.

\section{Cloning Analysis}

From the genomic DNA samples of 2006, genes for bacterial 16S rRNA were amplified with the primer pair $27 \mathrm{f}$ and 1492r [27]. The PCR amplification was initiated with $5 \mathrm{~min}$ of denaturation at $94^{\circ} \mathrm{C}$. The total cycle number was 30 , and each thermal cycle consisted of $60 \mathrm{~s}$ at $94^{\circ} \mathrm{C}$, $60 \mathrm{~s}$ at $46.7^{\circ} \mathrm{C}$, and $90 \mathrm{~s}$ at $72^{\circ} \mathrm{C}$. The additional extension was carried out for $10 \mathrm{~min}$ at $72^{\circ} \mathrm{C}$. The amplified fragments were ligated into the pCR2.1-TOPO vector (Invitrogen, Carlsbad, CA), and then introduced into 
competent TOP10 cells (Invitrogen). From the established library, colonies were randomly picked for further analysis. The regions including the cloned inserts were directly amplified from the cells by PCR, using the primer pair M13F (-20) and M13R. The resulting PCR products were digested with $\mathrm{Hae} I \mathrm{II}$ and $H h a \mathrm{I}$ for $1 \mathrm{~h}$ at $37^{\circ} \mathrm{C}$. The clones were grouped according to the resulting restriction fragment length polymorphism (RFLP), and then representative clones of each group were sequenced.

\section{Phylogenetic Analysis}

The sequences of DGGE bands were aligned with the related sequences retrieved from the DDBJ/EMBL/Genbank database, using the program ClustalX [51]. Genetic distances were calculated using the program MEGA3 [26] and phylogenetic trees were constructed using the neighborjoining method. The robustness of the trees obtained was examined with bootstrap tests of 500 replicates.

For phylogenetic analysis, bacterial clones with sequences similarities greater than $97 \%$ were grouped into same operational taxonomic units (OTUs). Phylogenetic positions of the defined OTUs were inferred with the same methods described above.

\section{Stable Isotope Analysis}

After freeze-dryness of red snow samples (ca. 5-50 g), we homogenized soft organic matter in the involatile residue. Nitrogen isotopic compositions of the bulk sample were determined using an elemental analyzer combined with an isotope ratio mass spectrometer (EA; Costech 4010 Elemental Analyzer, IRMS; Delta Plus Mass Spectrometer, ThermoFinnigan). We also used a Flash elemental analyzer (EA; EA1112, ThermoFinnigan) combined with an isotope ratio

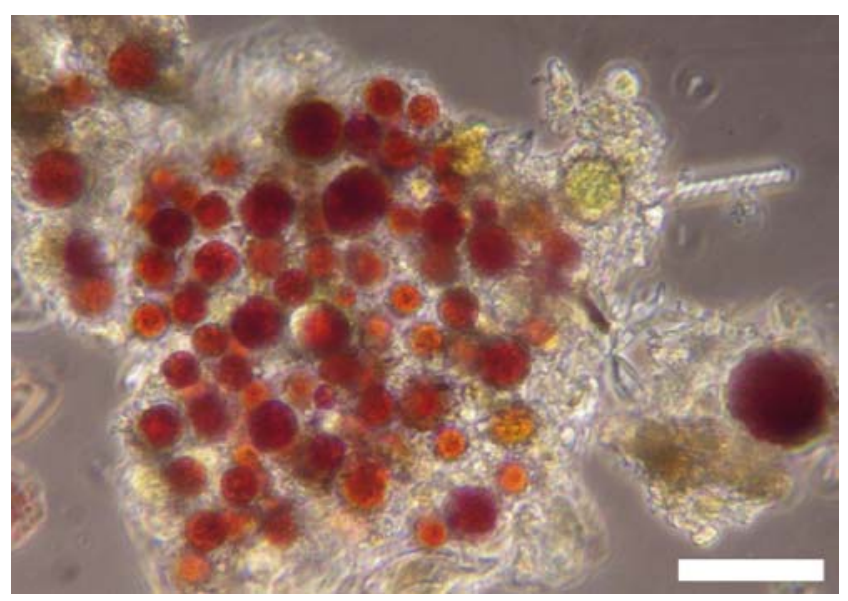

Figure 2 Microphotograph of the fresh red snow sample obtained in 2006. Bar indicates $50 \mu \mathrm{m}$

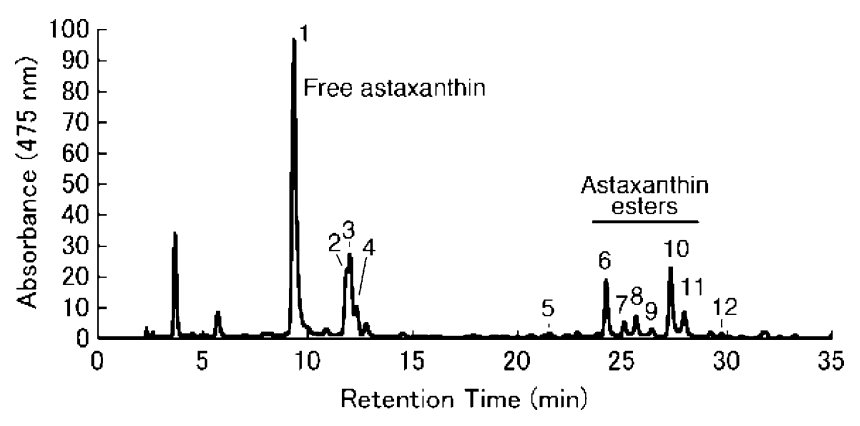

Figure 3 Chromatogram showing the result of pigment analysis on the sample obtained in 2006. 1-3 non-esterified astaxanthin, 4 lutein, 5 chlorophyll $b, 6-11$ astaxanthin esters, 12 pheophytin $a$

mass spectrometer (IRMS; Delta Plus XP, ThermoFinnigan) coupled with a Conflo III interface. Nitrogen isotopic compositions are expressed as conventional $\delta$ notation by the per mil (\%) deviation from the standard (vs. Air) as follows: $\delta^{15} \mathrm{~N}=\left[\left({ }^{15} \mathrm{~N} /{ }^{14} \mathrm{~N}\right)_{\text {sample }} /\left({ }^{15} \mathrm{~N} /{ }^{14} \mathrm{~N}\right)_{\text {standard }}-1\right] \times 1,000$ $(\%)$, with a high precision $(1 \sigma<0.5 \%$ o).

Nucleotide Sequence Accession Numbers

The nucleotide sequences determined in this study have been assigned the DDBJ/EMBL/GenBank accession numbers AB519653- AB519673.

\section{Results}

\section{Microscopic Observation}

In the red snow samples, various sizes of rounded red cells, ranging ca $10-40 \mu \mathrm{m}$ in diameter, were observed together with translucent amorphous materials (Fig. 2). The concentrations of red particles were $5.8 \times 10^{2} \mathrm{ml}^{-1}$ in the sample collected in 2006 , and $3.2 \times 10^{3} \mathrm{ml}^{-1}$ in the 2007 sample.

Pigment Composition

We analyzed the pigment composition of the red snow sample by HPLC according to the method of Sarada et al. [42]. The observed chromatogram (Fig. 3) was similar to those reported in previous studies with a green alga, Haematococcus pluvialis [33, 42, 58]. Based on the retention times and the absorbance spectra compared with the authentic trans-astaxanthin standard and those of previous reports [56, 57, 59], most of the major peaks (peaks 1-3, 6-11) were identified as the isomers of astaxanthin, which are frequently found in representative of snow algae $[2,9,53]$. We also analyzed masses of peaks $1-3$, and found that all of these peaks yielded massspectrometric signal of $597.39(\mathrm{~m} / z[\mathrm{M}+\mathrm{H}]+)$. These results demonstrated that peaks $1-3$ are non-esterified isomers of 
Figure 4 DGGE profile of eukaryotic SSU rRNA genes obtained from the red snow sample collected in 2006 and phylogenetic affiliations of the DGGE bands

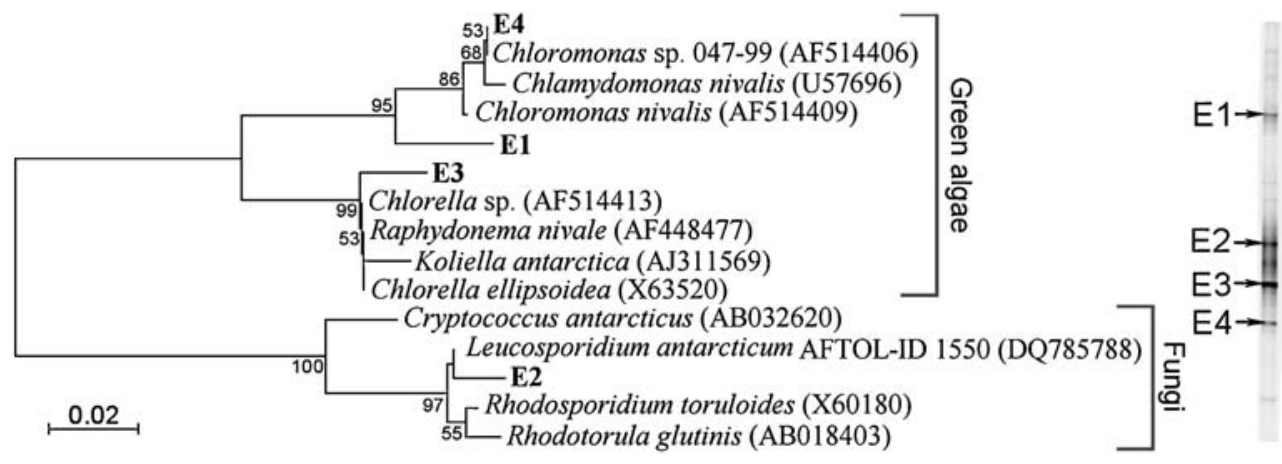

astaxanthin. We further identified peak 4, 5, and 12 as lutein, chlorophyll $b$, and pheophytin $a$, respectively, based on their retention times and absorption spectra compared with those of the pigments from $A$. thaliana (data not shown). We should note that we could not separate the peak of chlorophyll $a$ and peak 6 in our HPLC system, so that the chlorophyll $a$ peak of the red snow sample, if present, might have been masked by peak 6 .

\section{PCR-DGGE Analysis}

Community structure of microorganisms in the red snow was investigated with PCR-DGGE analysis targeting small subunit rRNA genes. The sample obtained in 2006 was subjected to DGGE analysis of eukaryotic rRNA genes, and four major bands were sequenced (Fig. 4). They were subjected to phylogenetic analysis, and one of the bands, E2 turned out to be related to a fungus. The other bands were inferred to have originated from algae belonging to the phylum Chlorophyta (Fig. 4).

In the analysis of $16 \mathrm{~S}$ rRNA gene, DGGE profiles of red snow were different between the samples of 2006 and 2007. In particular, appearance or disappearance of bands corresponding to algal chloroplast (underlined bands in Fig. 5) were profoundly different. The bands from the sample of 2006 were related to Vaucheria litorea (P1), Chlamydomonas reinhardtii (P2), and Chlorella saccharophila (P3; Table 1). Band P6 was detected only in the 2007 sample and was related to $C$. reinhardtii (Table 1). Other sequenced bands originated from bacteria belonging to the class Betaproteobacteria or the phylum Bacteroidedes (Table 1). These bands were detected from samples from both years, but their relative intensities were quite different between the two samples (Fig. 5). However, band P5 closely related to Hymenobacter sp. was detected in both samples as the most predominant band.

We also tried to analyze a sample of white snow obtained from the study site in 2006. Although large volume of snow melt was filtered (4 1), no PCR product was obtained with the same methods applied to the red snow samples.
Cloning Analysis

In the cloning analysis of $16 \mathrm{~S}$ rRNA genes, 86 clones were sorted into 12 OTUs based on RFLP patterns and sequence similarity. Those of three OTUs, comprising $36 \%$ of 86 clones, were inferred to have originated from algal chloroplasts. These three OTUs corresponded to the DGGE bands $\mathrm{P} 1, \mathrm{P} 2$, and $\mathrm{P} 3$, respectively. The OTU corresponding to band $\mathrm{P} 2$ was the most frequently detected OTU in the clone library (24 of 86 clones). As to bacterial clones, members of the phylum Bacteroidetes were frequently detected (three OTUs, 38 clones), and they all fell within the cluster of the genus Hymenobacter (Fig. 6). The other part of the library was comprised of bacteria belonging to the phyla Actinobacteria, Proteobacteria, and

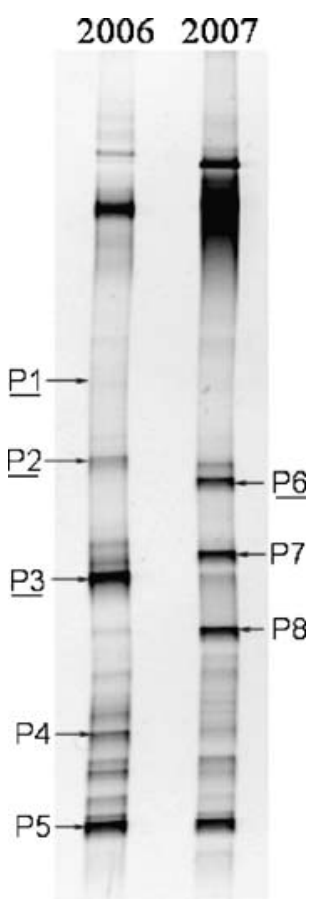

Figure 5 DGGE profile of 16S rRNA genes. Underlined bands were inferred to have originated from chloroplast of eukaryotic phototrophs 
Table 1 The closest relatives of DGGE band of 16S rRNA genes

\begin{tabular}{lllll}
\hline Band & Phylogenetic group & Closest identified relative (acc. no) & Identities & Assession no. \\
\hline P1 & Chloroplast & Vaucheria litorea(EU912438) & $445 / 473(94 \%)$ & AB519662 \\
P2 & Chloroplast & Chlamydomonas reinhardtii(X03269) & $319 / 366(87 \%)$ & AB519663 \\
P3 & Chloroplast & Chlorella saccharophilastrain 3.80 (D11348) & $349 / 402(86 \%)$ & AB519664 \\
P4 & Bacteroidetes & Hymenobactersp. 1004 (EF423320) & $430 / 451(95 \%)$ & AB519665 \\
P5 & Bacteroidetes & Hymenobactersp. CS10 (FM202729) & $403 / 454(88 \%)$ & AB519666 \\
P6 & Chloroplast & Chlamydomonas reinhardtiistrain CC-503 (FJ423446) & $432 / 502(86 \%)$ & AB519667 \\
P7 & Betaproteobacteria & Massiliasp. Asd M1A2 (FM955855) & $520 / 536(97 \%)$ & AB519668 \\
P8 & Betaproteobacteria & Oxalobacteraceae bacterium (EU057878) & $518 / 522(99 \%)$ & AB519669 \\
\hline
\end{tabular}

${ }^{\text {a }}$ According to the results of BLAST search excluding sequences from environmental samples

Cyanobacteria (Fig. 6). The OTU belonged to the phylum Actinobacteria was closely related to Frigoribacterium faeni, a psychrophilic heterotroph isolated from low-temperature environments [19]. Other sequences of the class Betaproteo- bacteria and the phylum Cyanobacteria were all similar to sequences detected from low-temperature environments such as a glacier and Antarctica [12, 48, 52], but no occurrence of red snow were reported from those sites.

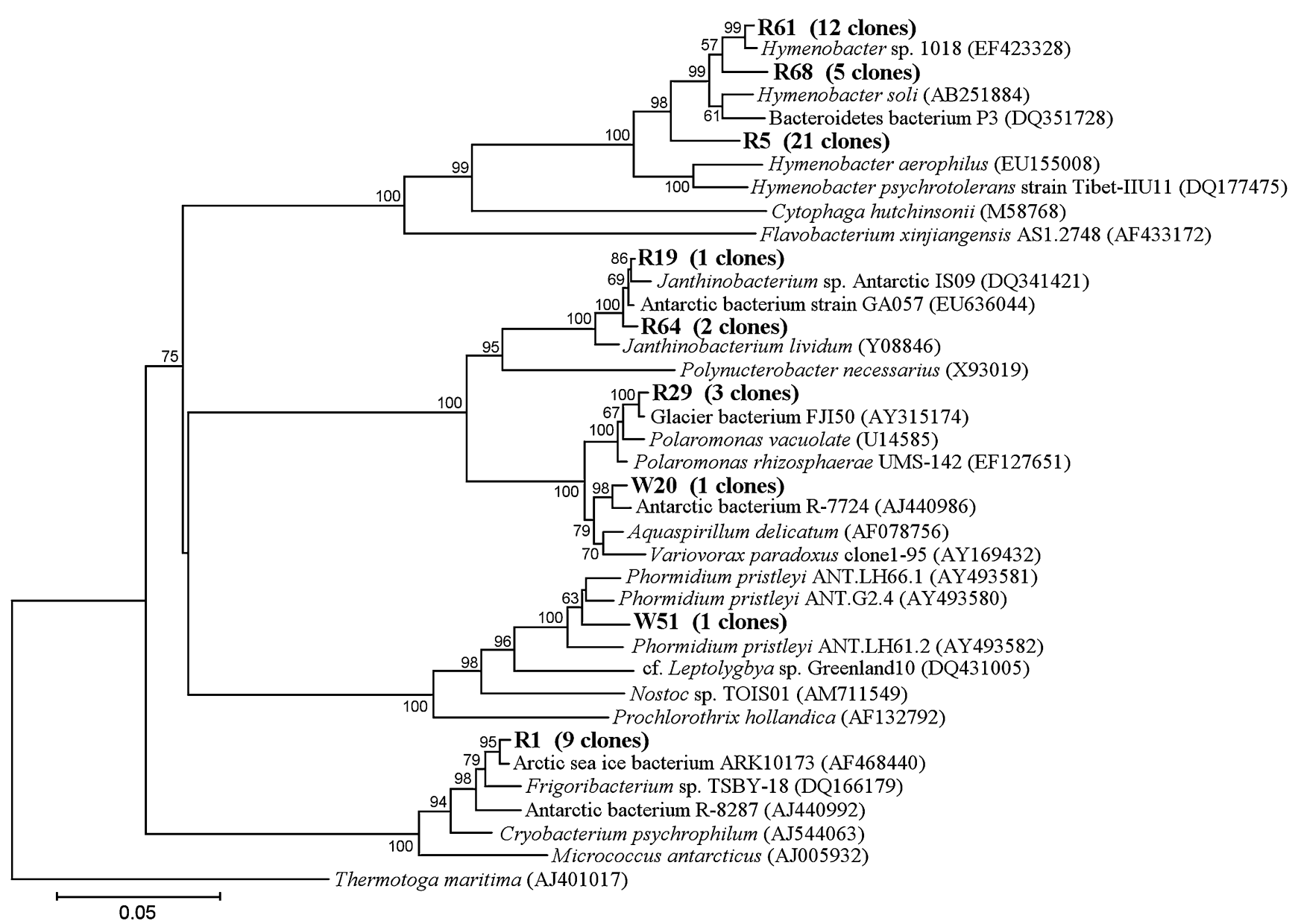

Figure 6 Phylogenetic affiliations of the bacterial OTUs obtained from the clone library. Numbers on nodes are percentage values of bootstrap resampling (values larger than 50 are shown) 
Stable Isotope Analysis

Stable isotope values of $\delta^{15} \mathrm{~N}$ were measured to deduce the source of nitrogen contained in the samples of red snow. Both of the red snow samples obtained in 2006 and 2007 indicated similar values of $\delta^{15} \mathrm{~N},+14.7 \%$ ( $(n=2)$ and $+14.3 \pm$ $1.1 \%$ o $(n=3)$, respectively. They were isotopically heavier than sediment and algal mat samples collected from the sites along Lützow-Holm Bay (Takano, unpublished data).

\section{Discussion}

Snow surface had been considered to be devoid of active life forms [7], because of harsh environmental conditions such as low temperature, low nutrient, and high irradiation of UV. However, the presence of diverse microorganisms in snow has been revealed by the increasing number of recent studies (e.g., [6, 43]). Snow algae are one of the most studied microorganisms present on the surface of snow, and they have significant effects on their own environments [15, $23,44,50]$.

Under microscopy, diverse microorganisms were observed in the red snow samples collected from Langhovde. As expected from faint color of the samples, concentrations of red cells were considerably lower than those in previous reports, as high as $10^{5}$ cells/ml [16]. The HPLC analysis demonstrated the predominant accumulation of astaxanthin in the sample (Fig. 3). Astaxanthin is a keto-carotenoid produced by bacteria, fungi, a group of unicellular alga and a few plant species $[8,18]$. The red snow sample also contained chlorophyll $b$, a photosynthetic pigment unique in green algae, land plants, and select groups of marine cyanobacteria [3]. Accordingly, we detected several species of green algae as both nuclear and plastid SSU rRNA gene sequences (Figs. 4 and 5). Most of these sequences were distinct from previously reported sequences of snow algae (Fig. 4). This may indicate uniqueness of the red snow in Antarctica. On the other hand, it might have resulted from incompleteness of the sequence database. Although there are many $18 \mathrm{~S}$ rRNA gene sequences of snow algae deposited on the public database, the majority are from cultured strains. As for snow algae in red snow, reports of direct sequence analysis without cultivation are still scarce in contrast to abundant examples of morphological descriptions. Considering possible bias induced by culturing, culture-independent analyses of various red snow samples are desirable to obtain phylogenetic information. Such analyses also may enable to investigate relationship between phylogeny and global distributions of snow algae.

The PCR-DGGE analysis of eukaryotic SSU rRNA gene indicated the presence of several species of algae in the red snow sample. In addition, chloroplasts of eukaryotic phototrophs were also detected in the DGGE analysis of 16S rRNA gene, and the detected chloroplasts were different between the samples from two years. Despite the differences in eukaryotic communities, bacteria related to Hymenobacter species were detected as predominant DGGE bands from the samples of both years. They were also detected as major members of the bacteria community in the cloning analysis. Strains of the genus Hymenobacter have been isolated from various environments including air, freshwater, grass soil, desert, permafrost, and Antarctic glacier $[1,4,5,21,22,61,62]$. The members of this genus are known to synthesize red or pink carotenoid [22]. Some of the astaxanthin detected in the red snow sample might have been produced by these bacteria. It is likely that bacteria of this genus are able to tolerate an excessive UV irradiation on the snow surface because of protection afforded by their own pigments. All known strains of this genus are aerobic heterotrophs, and capability for nitrogen fixation has not been found from them.

The stable isotope analysis revealed that the red snow samples were significantly ${ }^{15} \mathrm{~N}$-enriched compared to other terrestrial sandy soil, lacustrine sediment (glacier lake, brackish lake, and saline lake), and marine sediment of the Lützow-Holm Bay, East Antarctica (Takano, unpublished data). We also determined nitrogen isotopic compositions of bulk primary producers including Opal-A enriched fossil marine diatoms at Skallen $\left(\delta^{15} \mathrm{~N}_{\text {bulk }}<\right.$ $+6.1 \%$ ), Skarvsnes $\left(\delta^{15} \mathrm{~N}_{\text {bulk }}<+6.7 \%\right.$ ), and Langhovde $\left(\delta^{15} \mathrm{~N}_{\text {bulk }}<+4.7 \%\right.$ ) along the Lützow-Holm Bay (Takano, unpublished data). Although anomalous ${ }^{15} \mathrm{~N}$-enrichment of penguin rookeries affected by accumulated seabird fecal soil with abiotic volatilization process has been reported $[35,36]$, the sampling site of the present study is presumably inaccessible for penguin (e.g., Pygoscelis adeliae) because of its location in a steep valley (Fig. 1). Indeed, there is no penguin rookery along the Yukidori valley and Yatsude valley at Langhovde. The bulk nitrogen isotope analysis for food web elucidation is based on empirical observations that the conventional $\delta^{15} \mathrm{~N}(\%$, vs. Air) value of bulk organisms and their tissues tends to increase by 3.4\%o with each trophic level (e.g., [10, 34, 41, $60])$. Considering a scheme of the stepwise ${ }^{15} \mathrm{~N}$-enrichment of a food web, we could estimate the trophic level of a target organism by the equation,

Trophic level

$$
=\left(\delta^{15} \mathrm{~N}_{\text {sample }}-\delta^{15} \mathrm{~N}_{\text {primary producers }}\right) / 3.4+1
$$

where the equation needs $\delta^{15} \mathrm{~N}$ of primary producers to determine trophic level. The mean of $\delta^{15} \mathrm{~N}$ of abovementioned siliceous marine diatom in Skallen, Skarvsnes, and Langhovde was $+5.8 \pm 1.0 \%$. Subsequently, if we defined $+5.8 \%$ as $\delta^{15} \mathrm{~N}_{\text {primary producers }}$, the nitrogen sources 
Figure 7 Stepwise ${ }^{15} \mathrm{~N}$-enrichment along trophic levels and a hypothesis of linkage between seabirds in the food web and transportation of ${ }^{15} \mathrm{~N}$-enriched fecal pellet via aerial pathway as a trigger of red snow

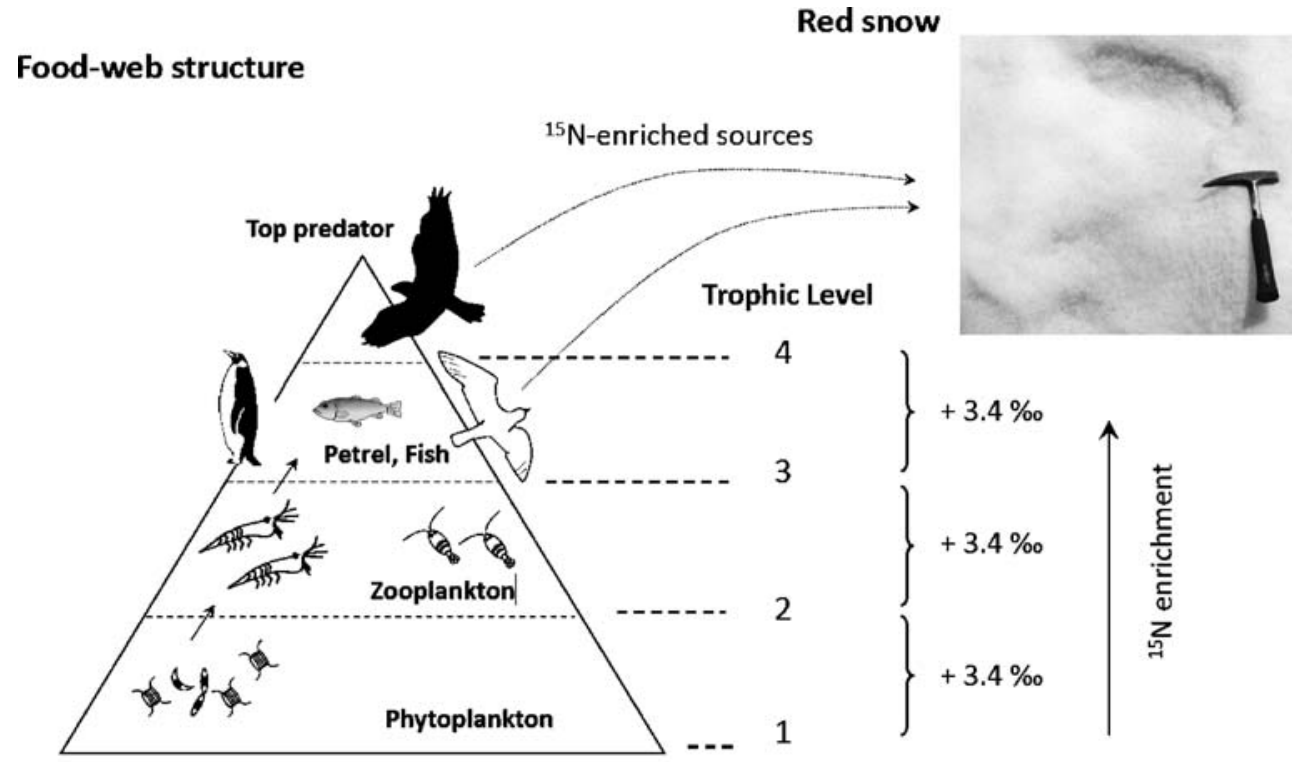

$$
\text { Trophic Level }=\frac{\delta^{15} N_{\text {sample }}-\delta^{15} N_{\text {primary producers }}}{3.4}+1
$$

of red snow samples were estimated for trophic level 3.5 to 3.6. Trophic level 3 organisms are a higher level than zooplankton, and trophic level 4 organisms are top predators in the region (Fig. 7). As an interpretation of
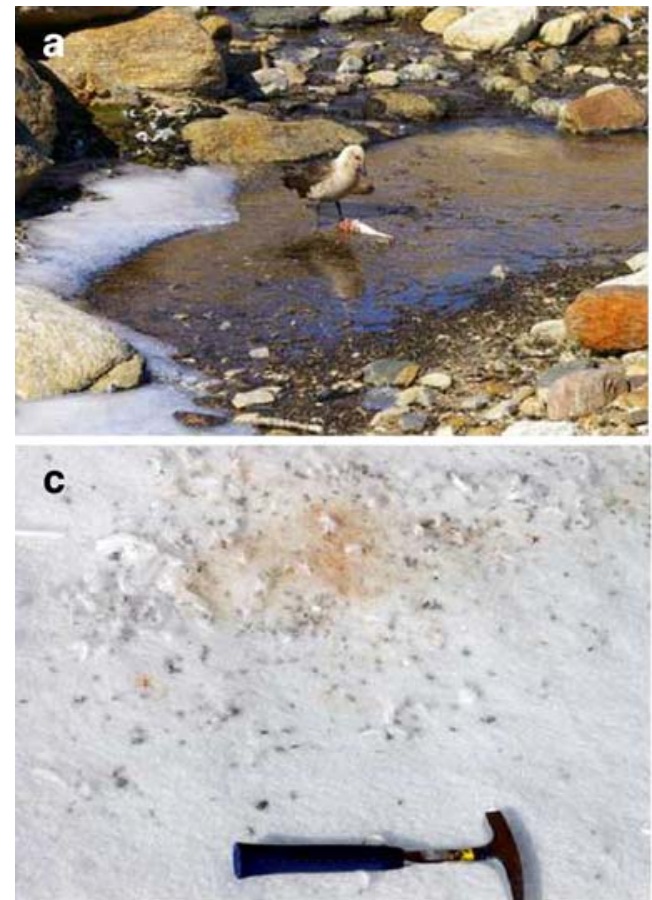

Figure 8 Seabird as a predator and prey in the food web at Langhovde: a a south polar skua preying on a snow petrel near sampling site. $\mathbf{b}$ a snow petrel in the nest at Yukidori valley. Note that accumulated fecal pellet in front of the nest. $\mathbf{c}$ a kill site on a snow
${ }^{15} \mathrm{~N}$-enriched red snow sample, we suggest it is plausible that organisms from a higher trophic level also could have transported ${ }^{15} \mathrm{~N}$-enriched material via aerial pathway. Yukidori valley in Langhovde $\left(69^{\circ} 14^{\prime} \mathrm{S}, 39^{\circ} 44^{\prime} \mathrm{E}\right)$, close to

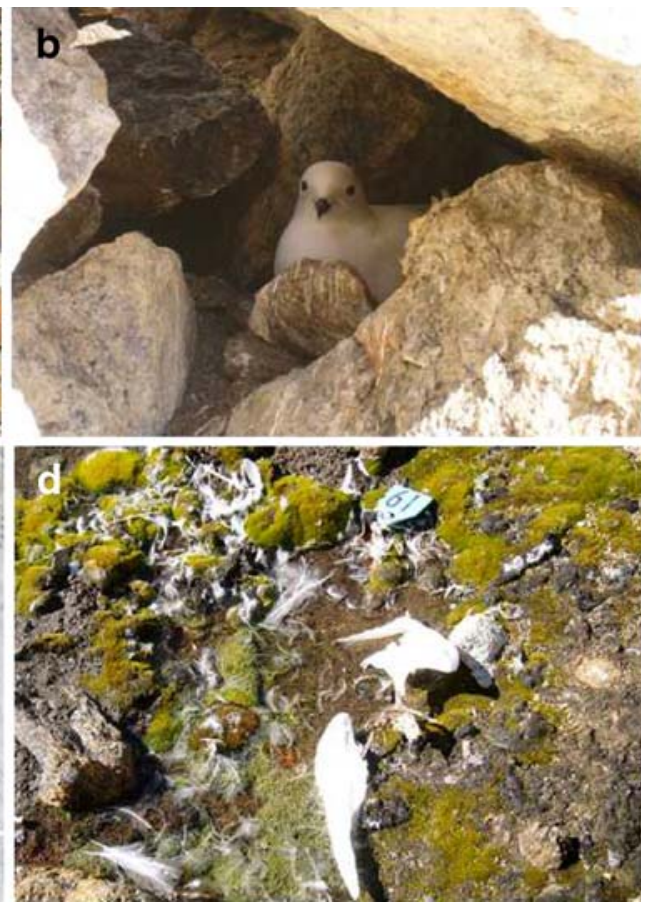

field at Yukidori valley. Note that the color of red is from fresh blood of a dead seabird, not from snow algal aggregate. $\mathbf{d}$ a kill site on the moss mat. The blue peg (No. 19) stands for a site number of moss vegetation monitoring [20] 
our sampling site (Fig. 1), is an Antarctica Specially Protected Area (ASPA) with the designated location No.141 (http://www.scar.org/treaty/, see also Scientific Committee on Antarctica Research, 2003). Yukidori valley is inhabited by a large number of snow petrels along the valley, and it is one of the nutrient sources for moss and lichen vegetation. Furthermore, the south polar skua, a common marine top predator in ice-free area of Antarctica $[31,40]$, also has several habitats near the sampling site (Fig. 8). The scientific party during the field study near Yukidori valley and Yatsude valley often observed predation between south polar skuas and snow petrels. Theoretically, our result of the trophic level (3.5-3.6) could be from trophic level 4 to 3 organisms, namely from south polar skua and snow petrel (Fig. 8).

The red snow samples found in Langhovde included plural species of green microalgae and the majority of associated bacteria seemed to be secondary inhabitants. Their primary nitrogen source appears to be supplied from seabirds, suggesting that presence of seabirds may affect red snow distribution significantly. This seems to be consistent with distribution of red snow in Antarctica, which is restricted to shore areas (e.g., [29]). Further studies in the Antarctic and other localities will be needed to test the universality of these findings, including roles of associated bacteria, sources of nutrient supply and their effects on distribution of red snow.

Acknowledgments The field research at ASPA No.141 was performed with the permission (M.F., Y.T., T.H.) of Ministry of Environment, Japan. The authors would like to thank the members of the 47th and 48th Japan Antarctica Research Expedition for their logistic assistance, N. Ohkouchi and N. O. Ogawa (Japan Agency for Marine-Earth Science and Technology) for their support. We thank the OPEN FACILITY center (Hokkaido Univ.) for the use of the AccuTOF system for ESI-MS measurement, especially S. Jin for his helpful suggestions. We also thank S. Matoba and M. Watanabe for providing data of ion chromatography. This research was supported in part by REGAL project of National Institute of Polar Research $(\mathrm{H}$. Kanda and S. Imura).

\section{References}

1. Baik KS, Seong CN, Moon EY, Park Y-D, Yi H, Chun J (2006) Hymenobacter rigui sp. nov., isolated from wetland freshwater. Int J Syst Evol Microbiol 56:2189-2192

2. Bidigare RR, Ondrusek ME, Kennicutt MC II, Iturriaga RH, Harvey R, Hoham RW, Macko SA (1993) Evidence a photoprotective for secondary carotenoids of snow algae. J Phycol 29:427-434

3. Bryant DA, Frigaard NU (2006) Prokaryotic photosynthesis and phototrophy illuminated. Trends Microbiol 14:488-496

4. Buczolits S, Denner EBM, Kämpfer P, Busse H-J (2006) Proposal of Hymenobacter norwichensis sp. nov., classification of 'Taxeobacter ocellatus', 'Taxeobacter gelupurpurascens' and 'Taxeobacter chitinovorans' as Hymenobacter ocellatus sp. nov., Hymenobacter gelipurpurascens sp. nov. and Hymenobacter chitinivorans sp. nov., respectively, and emended description of the genus Hymenobacter Hirsch et al. 1999. Int J Syst Evol Microbiol 56:2071-2078

5. Buczolits S, Denner EBM, Vybiral D, Wieser M, Kämpfer P, Busse H-J (2002) Classification of three airborne bacteria and proposal of Hymenobacter aerophilus sp. nov. Int J Syst Evol Microbiol 52:445-456

6. Carpenter EJ, Lin S, Capone DG (2000) Bacterial activity in South Pole snow. Appl Environ Microbiol 66:4514-4517

7. Cowan DA, Tow LA (2004) Endangered Antarctic environments. Annu Rev Microbiol 58:649-690

8. Cunningham FX Jr, Gantt E (2005) A study in scarlet: enzymes of ketocarotenoid biosynthesis in the flowers of Adonis aestivalis. Plant J 41:478-492

9. Czygan F-C (1970) Blutregen und Blutschnee: StickstoffmangelZellen von Haematococcus pluvialis und Chlamydomonas nivalis. Arch Microbiol 74:69-76

10. DeNiro MJ, Epstein S (1981) Influence of diet on the distribution of nitrogen isotopes in animals. Geochim Cosmochim Acta 45:341-351

11. Duval B, Duval E, Hoham RW (1999) Snow algae of the Sierra Nevada, Spain, and high Atlas mountains of Morocco. Int Microbiol 2:39-42

12. Foght J, Aislabie J, Turner S, Brown CE, Ryburn J, Saul DJ, Lawson W (2004) Culturable bacteria in subglacial sediments and ice from two southern hemisphere Glaciers. Microbiol Ecol 47:329-340

13. Fry B (2006) Stable isotope ecology. Springer, New York

14. Gast RJ, Dennett MR, Caron DA (2004) Characterization of protistan assemblages in the Ross Sea, Antarctica, by denaturing gradient gel electrophoresis. Appl Environ Microbiol 70:20282037

15. Goodman D (1971) Ecological investigations of ice worms on Casement Glacier, southeast Alaska. Inst Polar Studies, Ohio State Univ Res Found, Columbus Rep 39:1-59

16. Hoham RW, Duval B (2001) Microbial ecology of snow and freshwater ice with emphasis on snow algae. In: Jones HG, Pomeroy JW, Walker DA, Hoham RW (eds) Snow ecology: an interdisciplinary examination of snow-covered ecosystems. Cambridge University Press, Cambridge, pp 168-228

17. Hoham RW, Laursen AE, Clive SO, and Duval B (1993) Snow algae and other microbes in several alpine areas in New England. In Proc 50th Annual Eastern Snow Conf 165-173

18. Johnson EA, An GH (1991) Astaxanthin from microbial sources. Crit Rev Biotechnol 11:297-326

19. Kämpfer P, Rainey FA, Andersson MA, Lassila E-LN U, Ulrych BH-J, Weiss N, Mikkola R, Salkinoja-Salonen M (2000) Frigoribacterium faeni gen. nov., sp. nov., a novel psychrophilic genus of the family Microbacteriaceae. Int J Syst Evol Microbiol 50:355-363

20. Kanda H, Inoue M (1994) Ecological monitoring of moss and lichen vegetation in the Syowa Station area, Antarctica. Proc NIPR Symp Polar Biol 7:221-231

21. Kim K-H, Im W-T, Lee S-T (2008) Hymenobacter soli sp. nov., isolated from grass soil. Int J Syst Evol Microbiol 58:941-945

22. Klassen JL, Foght JM (2008) Differences in carotenoid composition among Hymenobacter and related strains support a tree-like model of carotenoid evolution. Appl Environ Microbiol 74:20162022

23. Kohshima S (1994) Ecological characteristics of the glacier ecosystem (in Japanese). Jpn J Ecol 44:93-98

24. Koizumi Y, Kojima H, Oguri K, Kitazato H, Fukui M (2004) Vertical and temporal shifts in microbial communities in the water column and sediment of saline meromictic Lake Kaiike (Japan), as determined by a $16 \mathrm{~S}$ rDNA-based analysis, and related to physicochemical gradients. Environ Microbiol 6:622-637 
25. Kol E (1968) A note on red snow from New Zealand. New Zealand J Bot 6:243-244

26. Kumar S, Tamura K, Nei M (2004) MEGA3: integrated software for Molecular Evolutionary Genetics Analysis and sequence alignment. Brief Bioinform 5:150-163

27. Lane DJ (1991) 16S/23 S rRNA sequencing. In: Stackebrandt E, Goodfellow M (eds) Nucleic acid techniques in bacterial systematics. Wiley, New York

28. Light JJ, Belcher JH (1968) A snow microflora in the Cairngorm Mountains, Scotland. Br Phycol Bull 3:471-473

29. Ling HU (1996) Snow algae of the Windmill Islands region, Antarctica. Hydrobiol 336:99-106

30. Lütz-Meindl U, Lütz C (2006) Analysis of element accumulation in cell wall attached and intracellular particles of snow algae by EELS and ESI. Micron 37:452-458

31. Malzof S, Quintana R (2008) Diet of the south polar skua Catharacta maccormicki and the brown skua C. antarctica lonnbergi at Cierva Point, Antarctic Peninsula. Polar Biol 31:827-835

32. Marchant HJ (1982) Snow algae from the Australian snowy mountain. Phycologia 21:178-184

33. Miao F, Lu D, Li Y, Zeng M (2006) Characterization of astaxanthin esters in Haematococcus pluvialis by liquid chromatography-atmospheric pressure chemical ionization mass spectrometry. Anal Biochem 352:176-181

34. Minagawa M, Wada E (1984) Stepwise enrichment of ${ }^{15} \mathrm{~N}$ along food chains: further evidence and the relation between $\delta^{15} \mathrm{~N}$ and animal age. Geochim Cosmochim Acta 48:1135-1140

35. Mizutani H, Hasegawa H, Wada E (1986) High nitrogen isotope ratio for soils of seabird rookeries. Biogeochem 2:221-247

36. Mizutani H, Kabaya Y, Wada E (1985) Ammonia volatilization and high ${ }^{15} \mathrm{~N} /{ }^{14} \mathrm{~N}$ ratio in a penguin rookery in Antarctica. Geochem J 19:323-327

37. Muyzer G, Teske A, Wirsen CO, Jannasch HW (1995) Phylogenetic relationships of Thiomicrospira species and their identification in deep-sea hydrothermal vent samples by denaturing gradient gel electrophoresis of 16S rDNA fragmen. Arch Microbiol 164:165-172

38. Newton APW (1982) Red-coloured snow algae in Svalbardsome environmental factors determining the distribution of Chlamydomonas nivalis (Chlorophyta volvocales). Polar Biol 1:167-172

39. Painter TH, Duval B, Thomas WH, Mendez M, Heintzelman S, Dozier J (2001) Detection and quantification of snow algae with an airborne imaging spectrometer. Appl Environ Microbiol 67:5267-5272

40. Pezzo F, Olmastroni S, Corsolini S, Focardi S (2001) Factors affecting the breeding success of the south polar skua Catharacta maccormicki at Edmonson Point, Victoria Land, Antarctica. Polar Biol 24:389-393

41. Post D (2002) Using stable isotopes to estimate trophic position: models, methods, and assumptions. Ecology 83:703-718

42. Sarada R, Vidhyavathi R, Usha D, Ravishankar GA (2006) An efficient method for extraction of astaxanthin from green alga Haematococcus pluvialis. J Agric Food Chem 54:7585-7588

43. Segawa T, Miyamoto K, Ushida K, Agata K, Okada N, Kohshima S (2005) Seasonal change in bacterial flora and biomass in mountain snow from the Tateyama Mountains, Japan, analyzed by 16S rRNA gene sequencing and real-time PCR. Appl Environ Microbiol 71:123-130
44. Shain DH, Mason TA, Farrell AH, Michalewicz LA (2001) Distribution and behavior of ice worms (Mesenchytraeus solifugus) in south-central Alaska. Can J Zool 79:1813-1821

45. Takeuchi N (2001) The altitudinal distribution of snow algae on an Alaska glacier (Gulkana Glacier in the Alaska Range). Hydrol Process 15:3447-3459

46. Takeuchi N, Dial R, Kohshima S, Segawa T, Uetake J (2006) Spatial distribution and abundance of red snow algae on the Harding Icefield, Alaska derived from a satellite image. Geophys Res Lett 33:L21502. doi:10.1029/2006GL027819

47. Takeuchi N, Kohshima S (2004) A snow algal community on Tyndall Glacier in the Southern Patagonia Icefield, Chile. Arct Antarct Alp Res 36:92-99

48. Taton A, Grubisic S, Ertz D, Hodgson DA, Piccardi R, Biondi N, Tredici MR, Mainini M, Losi D, Marinelli F, Wilmotte A (2006) Polyphasic study of Antarctic cyanobacterial strains. J Phycol 42:1257-1270

49. Thomas WH, Broady PA (1997) Distribution of coloured snow and associated algal genera in New Zealand. New Zealand $\mathrm{J}$ Bot 35:113-117

50. Thomas WH, Duval B (1995) Sierra Nevada, California, U.S.A., snow algae: snow albedo changes, algal-bacterial interrelationships, and ultraviolet radiation effects. Arct Alp Res 27:389-399

51. Thompson JD, Gibson TJ, Plewniak F, Jeanmougin F, Higgins DG (1997) The ClustalX windows interface: flexible strategies for multiple sequence alignment aided by quality analysis tools. Nucleic Acids Res 24:4876-4882

52. Trappen SV, Mergaert J, Eygen SV, Dawyndt P, Cnockaert MC, Swings J (2002) Diversity of 746 heterotrophic bacteria isolated from microbial mats from ten Antarctic Lakes. System Appl Microbiol 25:603-610

53. Viala G (1966) L'astaxanthine chez le Chlamydomonas nivalis Wille. Compt Rend Hebd Seances Acad Sci 263:1383-1386

54. Weiss RL (1983) Fine structure of the snow alga (Chlamydomonas nivalis) and associated bacteria. J Phycol 19:200-204

55. Williams WE, Gorton HL, Vogelmann TC (2003) Surface gasexchange processes of snow algae. Proc Natl Acad Sci USA 100:562-566

56. Yuan JP, Chen F (1997) Identification of astaxanthin isomers in Haematococcus lacustris by HPLC-photodiode array detection. Biotechnol Tech 11:455-459

57. Yuan JP, Chen F (1998) Chromatographic separation and purification of trans-astaxanthin from the extracts of Haematococcus pluvialis. J Agric Food Chem 46:3371-3375

58. Yuan JP, Chen F (1999) Hydrolysis kinetics of astaxanthin esters and stability of astaxanthin of Haematococcus pluvialis during saponification. J Agric Food Chem 47:31-35

59. Yuan JP, Chen F (1999) Isomerization of trans-astaxanthin to cisisomers in organic solvents. J Agric Food Chem 47:3656-3660

60. Zanden M, Rasmussen J (1999) Primary consumer $\delta^{13} \mathrm{C}$ and $\delta^{15} \mathrm{~N}$ and the trophic position of aquatic consumers. Ecology 80:1395-1404

61. Zhang G, Niu F, Busse H-J, Ma X, Liu W, Dong M, Feng H, An L, Cheng G (2008) Hymenobacter psychrotolerans sp. nov., isolated from the Qinghai-Tibet Plateau permafrost region. Int J Syst Evol Microbiol 58:1215-1220

62. Zhang Q, Liu C, Tang Y, Zhou G, Shen P, Fang C, Yokota A (2007) Hymenobacter xinjiangensis sp. nov., a radiation-resistant bacterium isolated from the desert of Xinjiang, China. Int J Syst Evol Microbiol 57:1752-1756 